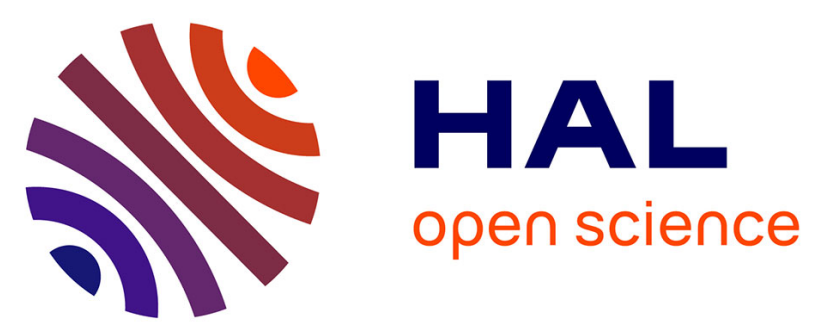

\title{
Isoprene oxidation products are a significant atmospheric aerosol component
}

S. N. Matsunaga, C. Wiedinmyer, A. B. Guenther, J. J. Orlando, T. Karl, D. W. Toohey, J. P. Greenberg, Y. Kajii

\section{- To cite this version:}

S. N. Matsunaga, C. Wiedinmyer, A. B. Guenther, J. J. Orlando, T. Karl, et al.. Isoprene oxidation products are a significant atmospheric aerosol component. Atmospheric Chemistry and Physics Discussions, 2005, 5 (6), pp.11143-11156. hal-00301899

\section{HAL Id: hal-00301899 \\ https://hal.science/hal-00301899}

Submitted on 2 Nov 2005

HAL is a multi-disciplinary open access archive for the deposit and dissemination of scientific research documents, whether they are published or not. The documents may come from teaching and research institutions in France or abroad, or from public or private research centers.
L'archive ouverte pluridisciplinaire HAL, est destinée au dépôt et à la diffusion de documents scientifiques de niveau recherche, publiés ou non, émanant des établissements d'enseignement et de recherche français ou étrangers, des laboratoires publics ou privés. 


\section{Isoprene oxidation products are a significant atmospheric aerosol component}

S. N. Matsunaga ${ }^{1,2}$, C. Wiedinmyer ${ }^{2}$, A. B. Guenther ${ }^{2}$, J. J. Orlando ${ }^{2}$, T. Karl ${ }^{2}$, D. W. Toohey ${ }^{3}$, J. P. Greenberg ${ }^{2}$, and Y. Kajii ${ }^{1}$

${ }^{1}$ Applied Chemistry Division, Faculty of Engineering, Tokyo Metropolitan University, 1-1 Minami-Ohsawa, Hachioji, Tokyo, 192-0397, Japan

${ }^{2}$ Atmospheric Chemistry Division, National Center for Atmospheric Research, 1850 Table Mesa Drive, Boulder, CO 80305, USA

${ }^{3}$ Program in Atmospheric and Oceanic Sciences and Program in Environmental Studies, University of Colorado, Stadium 255, 311 UCB, Boulder, CO 80309, USA

Received: 5 September 2005 - Accepted: 19 October 2005 - Published: 2 November 2005 Correspondence to: S. N. Matsunaga (smatsu@ucar.edu)

(c) 2005 Author(s). This work is licensed under a Creative Commons License.
Isoprene oxidation products in the

aerosols

S. N. Matsunaga et al.

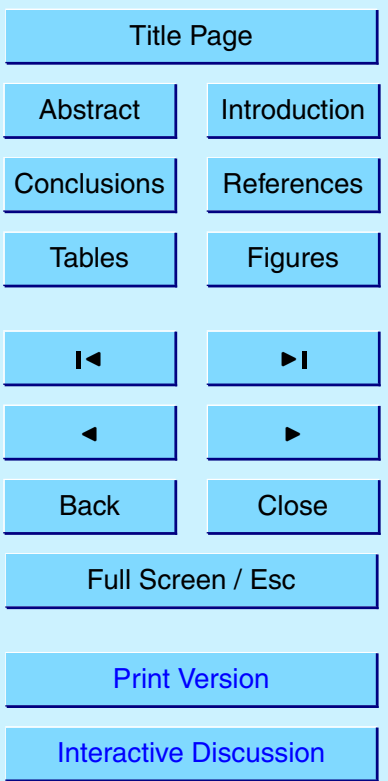




\section{Abstract}

Glycolaldehyde, hydroxyacetone, and methylglyoxal, which are known isoprene oxidation products, were collected during two field experiments using an annular denuder sampling system and compared to a model calculation. The compounds in gas and aerosol phases were determined during both experiments. Global variation and distribution of the aerosol mass contribution of the compounds were predicted using the measurements, the box model results, and gas-phase concentrations and humidity simulated by a global 3-D model. Here we report the estimates of a global annual contribution of 35 (10-120) Tg of aerosol organic matter from isoprene.

\section{Introduction}

Isoprene is released in large quantities from the biosphere (Guenther et al., 1995). Due to its high emission rate and reactivity, isoprene is one of the most important hydrocarbons in the atmosphere and has a substantial impact on tropospheric oxidants (Trainer et al., 1987). It has generally been accepted that isoprene does not contribute to secondary organic aerosol unlike most other biogenic terpenoid compounds (Kavouras et al., 1998). The major oxidation products of isoprene (glycolaldehyde; GA, hydroxyacetone; $\mathrm{HA}$, and methylglyoxal; $\mathrm{MG}$ ) have not been considered to be significant aerosol constituents due to their relatively high vapour pressure and the difficulty in measuring these compounds.

\section{Experiment}

Gaseous and particulate water soluble organic compounds (WSOC), including isoprene oxidation products, were collected during two field experiments using an annular denuder sampling system (ADSS: Gundel et al., 1995; Matsunaga et al., 2004). The experiments were conducted from 9 to 12 July 2003 in Duke Forest, Chapel Hill, NC,

\section{ACPD}

5, 11143-11156, 2005

\section{Isoprene oxidation products in the aerosols}

S. N. Matsunaga et al.

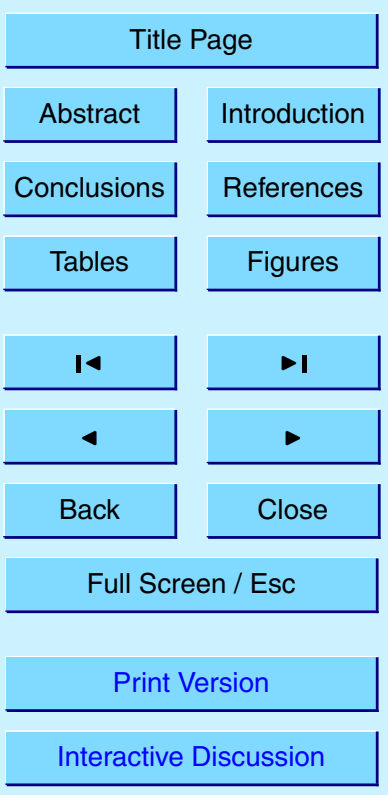

EGU 
USA and from 9 to 17 June 2004 in a poplar plantation near Boardman, OR, USA. Aerosol partition ratios (APRs) of these compounds ([Particle]/([Gas]+[Particle])\%) varied from 10 to $60 \%$. Concentrations of other volatile organic compounds (VOCs, including isoprene, methacrolein [MACR] and methyl vinyl ketone [MVK]), oxides of nitrogen $5 \quad\left(\mathrm{NO}_{\mathrm{x}}\right)$, ozone $\left(\mathrm{O}_{3}\right)$, light intensity, and meteorological conditions were also measured during the Duke Forest study. Production yields of the oxidation products from isoprene at Duke Forest were estimated using a chemical box model, the NCAR Master Mechanism (NMM: Bey et al., 1997; Aumont et al., 2000). Global variation and distribution of the aerosol mass contribution from $\mathrm{GA}, \mathrm{HA}$, and MG were predicted using 10 the measurements, the box model results, and gas-phase concentrations and humidity simulated by the global Model for OZone and Related chemical Tracers (MOZART: Horowitz et al., 2003).

\subsection{Sampling and analytical procedure}

The WSOCs in gas and aerosol phases were collected by the ADSS. The ADSS mainly 15 consists of two multi channel annular denuder tubes and a quartz fiber filter. The denuder tube is followed by the filter and a backup denuder. The inner walls of these denuder tubes are coated with an adsorbent (XAD-7) and $O$-benzylhydroxylammonium as a derivatization reagent. Gaseous compounds were trapped onto and derivatized on the inner wall of the denuder tube (URG-2000-30×242-3CSS). Particulate compounds 20 went through the tube and were collected on the filter and in the backup denuder. The derivatives were extracted from the denuder tubes by methanol in situ and analyzed with a GC/FID. The WSOCs on the filters were extracted and analyzed in the laboratory. The flow rate for the air sampling was $10 \mathrm{~L} \mathrm{~min}^{-1}$ and it was controlled by a mass flow controller. Sampling times were about $2 \mathrm{~h}$ at daytime and $4 \mathrm{~h}$ at night time. Details 25 about the ADSS and analytical technique are described in Matsunaga et al. (2004) and Matsunaga and Kawamura (2000), respectively.
ACPD

$5,11143-11156,2005$

\section{Isoprene oxidation products in the aerosols}

S. N. Matsunaga et al.

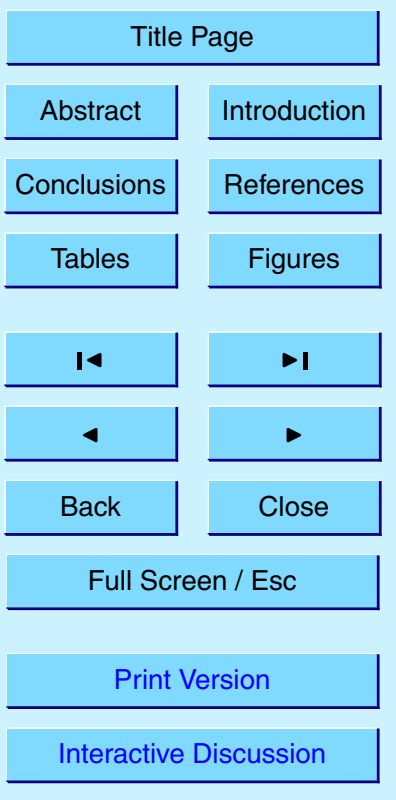

EGU 
$\mathrm{GA}, \mathrm{HA}$, and $\mathrm{MG}$ are second generation isoprene oxidation products that are produced by oxidation of the first generation isoprene oxidation products MACR and MVK (Tuazon and Atkinson, 1989, 1990; Atkinson, 1990). The relationship between isoprene emission and these products is clearly demonstrated by the results of the Boardman study. Here, the poplar plantation has extremely high isoprene emissions and is surrounded by a region of desert shrubland and irrigated crops with relatively low biogenic and anthropogenic hydrocarbon emissions. Air samples were simultaneously collected inside and outside of the plantation. The observed concentrations of GA, HA, and MG were highest at the downwind edge of the plantation and lowest at the upwind edge of the plantation. These results strongly suggest that the measured $G A, H A$, and MG were derived from the oxidation of isoprene emitted by the plantation's poplar trees. The observations also indicate that these compounds exist in aerosol phase outside of the tree plantation.

\section{Results and discussion}

\subsection{Box model calculation}

\subsubsection{Comparison of the concentration between the model and the measurement}

Figure 1 presents a comparison of the sum of MACR and MVK concentrations observed and simulated for Duke Forest on 10 July 2003. The modelled values were calculated with a zero dimensional chemical reaction model, NMM, which includes detailed chemical reactions of important alkanes, alkenes, and aromatics. The comparison in Fig. 1 indicates that the NMM box model, which was constrained by the observations of isoprene, $\mathrm{NO}_{\mathrm{x}}$ and ozone, accurately re-produced the concentration and diurnal variation of MACR and MVK, which are the precursors of $G A, H A$, and MG.

\section{Isoprene oxidation products in the aerosols}

S. N. Matsunaga et al.

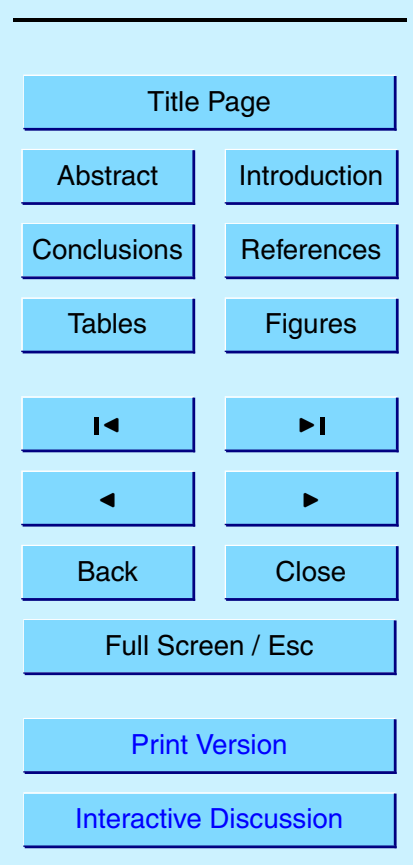


Figure 2a-c shows comparisons of the observed and NMM estimated total concentrations of $G A, H A$, and $M G$ for the same time period. Estimated concentrations of $G A$ and $H A$ were higher than measured values, probably due to an underestimation of their deposition rates. All of the observed GA and HA at Duke Forest could be explained 5 by isoprene oxidation. GA is also produced by oxidation of methylbutenols; however, methylbutenols were minor constituents at the Duke Forest site. Modelled MG concentrations were almost half of the measured concentrations. This suggests that MG has precursors other than isoprene, which is supported by a previous study (Atkinson, $1989,2000)$. Around half of the measured MG is assumed to be derived from isoprene.

10 3.1.2. Aerosol mass contributions of the $\mathrm{GA}, \mathrm{HA}$ and $\mathrm{MG}$ by the oxidation of isoprene

The yields of these compounds $\left(Y_{\mathrm{GA}}, Y_{\mathrm{HA}}\right.$, and $\left.Y_{\mathrm{MG}}\right)$ from isoprene oxidation were estimated with the NMM results (e.g. GA):

$Y_{\mathrm{GA}}=(d[\mathrm{GA}] / d t) /(-d[$ Isoprene $] / d t)$

Estimates of the contribution of GA, HA, and MG to aerosol mass (aerosol mass contribution; $A M C$ ) require not only the total chemical yield (calculated with Eq. 1), but also the aerosol partition ratios (APRs) for each compound. The APRs of GA, HA, and $M G$ are determined by the ADSS measurements. The APRs of the WSOCs such as $\mathrm{GA}, \mathrm{HA}$, and MG have been found to be highly dependent on relative humidity $(R H$ : Matsunaga et al., 2004). Although Henry's law constants of these compounds are very 20 large $\left(10^{4}-10^{6} \mathrm{~mol} \mathrm{~kg}^{-1} \mathrm{~atm}^{-1}\right)$, their aerosol partition ratios can not be explained only by Henry's law. Polymerization and/or other transformation of these compounds in the aerosol phase may support the observed partitioning (Jang and Kamens, 2001). It is most likely that the polymerized WSOC molecules decompose back to their original structure during the analytical process used for this study. In their polymerized form, these compounds could explain part of the humic-like substances that have recently been observed in laboratory experiments investigating the contribution of isoprene oxidation to secondary organic aerosol composition (Limbeck et al., 2003). Similar poly-
ACPD

5, 11143-11156, 2005

\section{Isoprene oxidation products in the aerosols}

S. N. Matsunaga et al.

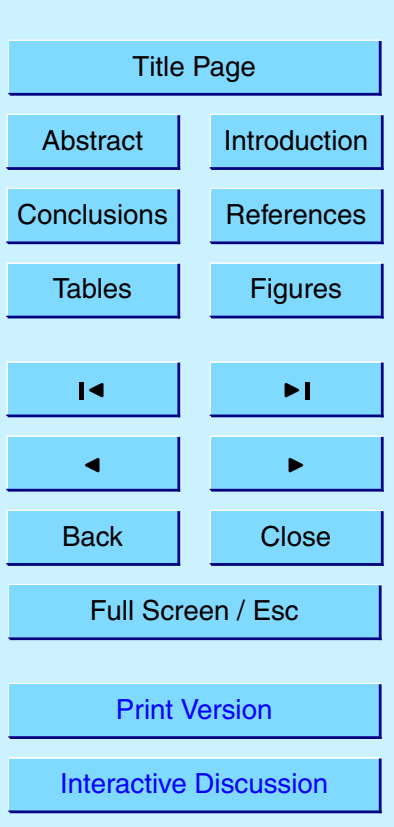

EGU 
merization by glyoxal has also been observed (Liggio et al., 2005). As seen in Fig. 3ac, a linear relationship between the $A P R$ and humidity was confirmed by the Duke Forest (this study) and Boardman experiments (this study) and by two previous experiments in Japan, although these experiments have been conducted in largely different 5 conditions. The experiments in Japan were conducted at Moshiri, Hokkaido Island in Japan on August, 2002 and at Tokyo Metropolitan University in Hachioji, Tokyo, Japan on May, 2004. These two experiments are described in Matsunaga et al.(2004, 2005), respectively. Empirically obtained equations for each $A P R$ are given below:

$$
A P R_{\mathrm{GA}}=0.47 R H-0.08
$$

$A P R_{\mathrm{HA}}=0.31 R H+0.11$

$A P R_{\mathrm{MG}}=0.31 R H+0.08$

Due to analytical uncertainly and $r^{2}$ values $<1, A P R$ s estimated by the equations are expected to have errors. The errors associated with the APRs (due to the dispersion of the APRs from the regression line and uncertainties in the analytical and measurement procedures) are estimated to be $75 \%(\mathrm{GA}), 62 \%(\mathrm{HA})$, and $71 \%(\mathrm{MG})$.

The aerosol mass contribution $(A M C)$ of the isoprene oxidation products are calculated with the following equation (e.g. GA):

$A M C_{\mathrm{GA}}=F_{\text {isoprene }} * Y_{\mathrm{GA}} * A P R_{\mathrm{GA}}$

where, $A M C_{\mathrm{GA}}$ is the aerosol mass contribution of $\mathrm{GA}$ per unit area and time, and 20

\subsection{Global contributions of the oxidation products}

To estimate the global $A M C$ from GA, HA, and MG, Eq. (3) was applied using global estimates of isoprene emissions and other controlling variables. The chemical production yields of $\mathrm{GA}, \mathrm{HA}$, and $M G$ for various conditions were estimated using the results
ACPD

$5,11143-11156,2005$

\section{Isoprene oxidation products in the aerosols}

\section{S. N. Matsunaga et al.}

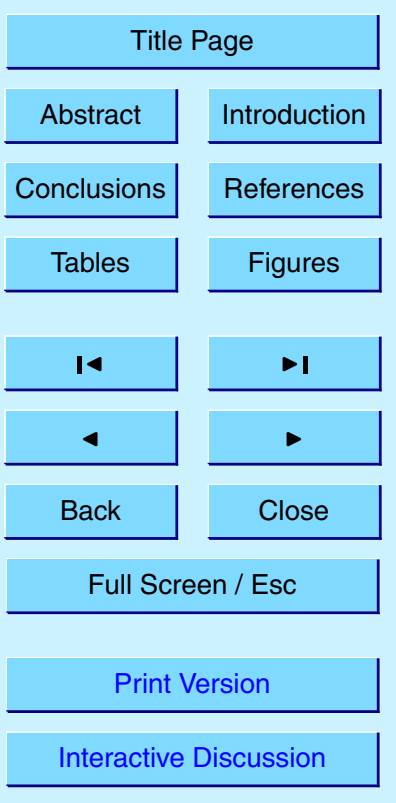

EGU 
of a sensitivity study with the NMM. The yields were found to be significantly impacted by changes in the concentrations of $\mathrm{NO}_{x}, \mathrm{O}_{3}$, and isoprene. For this study, the $\mathrm{NO}_{x}$, $\mathrm{O}_{3}$, and isoprene were varied in the $\mathrm{NMM}$, and the chemical yields of $\mathrm{GA}, \mathrm{HA}$, and MG were simulated. Concentrations of $\mathrm{NO}_{x}, \mathrm{O}_{3}$, and isoprene for the model simula5 tions ranged from $0.010-5.0,10-100$, and $0.050-4.0 \mathrm{ppbv}$, respectively. Calculated yields based on the NMM (Eq. 1) of GA, HA, and MG were 0.020-0.094, 0.027-0.12, and $0.014-0.084$, respectively. A multiple regression for these 25 model runs determined strong correlations between the yields and the concentrations of $\mathrm{NO}_{\mathrm{x}}, \mathrm{O}_{3}$, and isoprene. Statistically obtained equations parameterize the NMM output yields:

${ }_{10} Y_{\mathrm{GA}}=8.49 \times 10^{-2}\left[\mathrm{NO}_{\mathrm{x}}\right]^{0.15}+2.64 \times 10^{-3}[$ Isoprene $]-1.70 \times 10^{-4}\left[\mathrm{O}_{3}\right]-9.20 \times 10^{-3}(4 \mathrm{a})$ $Y_{\mathrm{HA}}=8.26 \times 10^{-2}\left[\mathrm{NO}_{\mathrm{x}}\right]^{0.2}-4.38 \times 10^{-3}[$ Isoprene $]-1.30 \times 10^{-4}\left[\mathrm{O}_{3}\right]+2.37 \times 10^{-2}(4 \mathrm{~b})$ $Y_{M G}=5.68 \times 10^{-2}\left[\mathrm{NO}_{\mathrm{x}}\right]^{0.1}+1.07 \times 10^{-2}[$ Isoprene $]+3.60 \times 10^{-4}\left[\mathrm{O}_{3}\right]-3.54 \times 10^{-2}(4 \mathrm{c})$

Global distributions of the monthly mean concentrations of $\mathrm{NO}_{\mathrm{x}}, \mathrm{O}_{3}$, and isoprene were simulated with MOZART on a Gaussian grid with approximately $2.3^{\circ}$ resolution. 15 MOZART is a 3-dimensional global chemistry and transport model used to examine the chemical and physical processes that control distributions of atmospheric constituents such as $\mathrm{O}_{3}$ and related trace compounds. Global distributions of the yields and the APRs of $\mathrm{GA}, \mathrm{HA}$, and $\mathrm{MG}$ were calculated for each month using monthly-averaged MOZART output and the regression results from the NMM. The global aerosol mass contribution of each of the isoprene oxidation products was then calculated using Eq. (3). The $A M C$ s were multiplied by the area of each global grid to determine the aerosol mass derived from isoprene oxidation products. Deviations between the yields predicted by the Eqs. (4a)-(4c) and calculated by the NMM ranged from $13 \%(\mathrm{HA})$ $-18 \%(\mathrm{GA})$. Uncertainties in the isoprene flux $\left(F_{\text {isoprene }}\right)$ and in the concentrations of $25 \mathrm{NO}_{\mathrm{x}}, \mathrm{O}_{3}$ and isoprene were estimated to be $<200 \%$. As a result, assumed errors for the yields are $210 \%\left(Y_{\mathrm{GA}}\right), 170 \%\left(Y_{\mathrm{HA}}\right)$ and $150 \%\left(Y_{\mathrm{MG}}\right)$. Considering all errors, the
ACPD

$5,11143-11156,2005$

\section{Isoprene oxidation products in the aerosols}

S. N. Matsunaga et al.

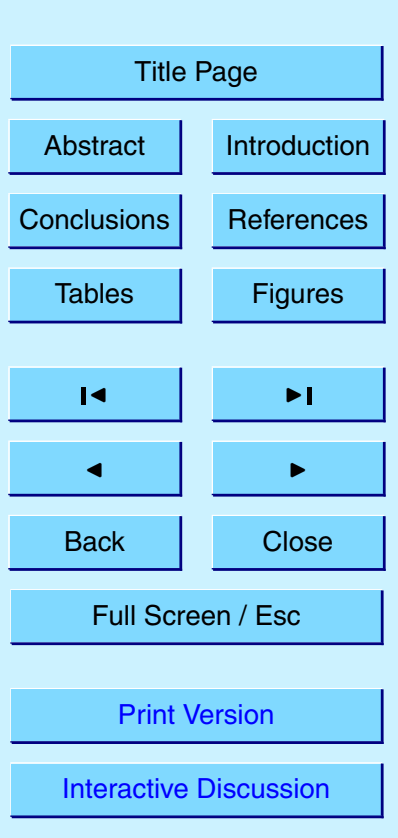

EGU 
uncertainties of the $A M C$ s are estimated to be $250 \%\left(A M C_{\mathrm{GA}}\right), 240 \%\left(A M C_{\mathrm{HA}}\right)$ and $230 \%\left(A M C_{\mathrm{MG}}\right)$.

Table 1 presents estimated annual $A M C$ of these compounds derived only from isoprene. Total annual $A M C$ s from the isoprene oxidation products $\mathrm{GA}, \mathrm{HA}$, and $\mathrm{MG}$ were 5 estimated to be $35(10-120) \mathrm{Tg} \mathrm{yr}^{-1}$ [16 (4.7-55) $\left.\mathrm{TgC} \mathrm{yr}^{-1}\right]$. This accounts for a large part of estimated global biogenic secondary organic aerosol (30-270 $\mathrm{Tg} \mathrm{yr}^{-1}$ : Andreae and Crutzen, 1997) and is comparable to the aerosol mass derived from monoterpenes (5-60 $\mathrm{Tg} \mathrm{yr}^{-1}$ : Kanakidou et al., 2005; Griffin et al., 1999).

The impact of isoprene oxidation in the atmosphere could be substantially larger than previously estimated (Claeys et al., 2004). Our former work (Matsunaga et al., 2003) estimated the global $A M C$ to be $0.19-0.68 \mathrm{Tg} \mathrm{yr}^{-1}$ by GA and $0.29-1.1 \mathrm{Tg} \mathrm{yr}^{-1}$ by HA. This is an order of magnitude lower than the estimate from this study. The difference in the results of the two studies is primarily due to the fact that the previous study related the isoprene flux to monoterpenes and assumed that the ratio of monoterpene and isoprene fluxes was globally constant. This assumption results in a large underestimation of isoprene emissions particularly in tropical regions. Finally, these isoprene oxidation products are highly water soluble; therefore, aerosols containing these compounds should be effective cloud condensation nuclei. This indicates that isoprene may have a significant role in the processes that control the global climate.

\section{4. Conclusions}

Aerosol mass contributions of isoprene oxidation products have been estimated based on field measurements, chemical box model and 3-D global chemical model calculation, and the estimated values were $35(10-120) \mathrm{Tg} \mathrm{yr}^{-1}$ [16 (4.7-55) $\mathrm{TgC} \mathrm{yr}^{-1}$ ]. This result indicates isoprene should be regarded as a significant precursor of organic 25 aerosol composition.

Acknowledgement. We thank T. Saito for valuable discussions and also thank for G. Petron and L. Emmons for infomation about the MOZART output. This study was supported by the

ACPD

5, 11143-11156, 2005

\section{Isoprene oxidation products in the aerosols}

S. N. Matsunaga et al.

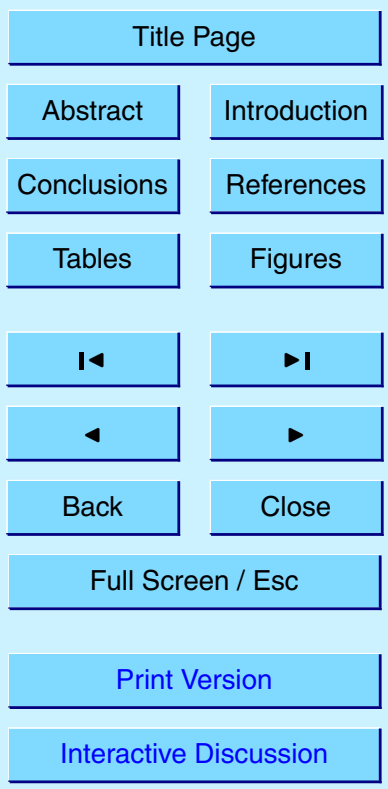

EGU 
Japan Society for the Promotion of Science (No. 08799), U.S. Environmental Protection Agency and the National Center for Atmospheric Research which is sponsored by National Science Foundation.

\section{References}

5 Andreae, M. O. and Crutzen, P. J.: Atmospheric aerosols: Biogeochemical sources and role in atmospheric chemistry, Science, 276, 1052-1058, 1997.

Atkinson, R.: Kinetics and mechanisms of the gas-phase reactions of the hydroxyl radical with organic compounds, J. Phys. Chem. Ref. Data, 1, 1-246, 1989.

Atkinson, R.: Gas-Phase Tropospheric Chemistry of Organic Compounds: A Review, Atmos. Environ., 24A, 1-41, 1990.

Atkinson, R.: Atmospheric chemistry of VOCs and $\mathrm{NO}_{\mathrm{x}}$, Atmos. Environ., 34, 2063-2101, 2000.

Aumont, B., Madronich, S., Bey, I., and Tyndall, G. S.: Contribution of secondary VOC to the composition of aqueous atmospheric particles: A model approach, J. Atmos. Chem., 35, $15 \quad 59-75,2000$.

Bey, I., Aumont, B., and Toupance, G.: The nighttime production of $\mathrm{OH}$ radicals in the continental troposphere, Geophys. Res. Lett., 24, 1067-1070, 1997.

Claeys, M., Graham, B., Vas, G., et al.: Formation of secondary organic aerosols through photooxidation of isoprene, Science, 303, 1173-1176, 2004.

Griffin, R. J., Cocker III, D. R., Seinfeld, J. H., and Dabdub, D.: Estimate of global atmospheric organic aerosol from oxidation of biogenic hydrocarbons, Geophys. Res. Lett., 26, 27212724, 1999.

Guenther, A., Hewitt, C. N., Erickson, D., et al.: A global model of natural volatile organic compound emissions, J. Geophys. Res., 100, 8873-8892, 1995.

25 Gundel, L. A., Lee, V. C., Mahanama, K. R. R., et al.: Direct determination of the phase distributions of semi-volatile polycyclic aromatic hydrocarbons using annular denuders, Atmos. Environ., 29, 1719-1733, 1995.

Horowitz, L. W., Walters, S., Mauzerall, D. L., et al.: A global simulation of tropospheric ozone and related tracers: Description and evaluation of MOZART, version 2, J. Geophys. Res., 108, 4784, doi:10.1029/2002JD002853, 2003.

Jang, M. and Kamens, R. M.: Atmospheric secondary aerosol formation by heterogeneous

\section{Isoprene oxidation products in the aerosols}

S. N. Matsunaga et al.

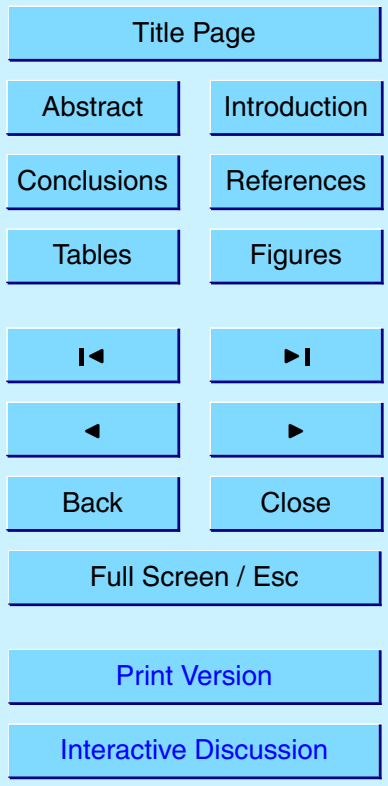

EGU 
reactions of aldehydes in the presence of a sulfuric acid aerosol catalyst, Environ. Sci. Technol., 35, 4758-4766, 2001.

Kanakidou, M., Seinfeld, J. H., Pandis, S. N., et al.: Organic aerosol and global climate modeling: a review, Atmos. Chem. Phys., 5, 1053-1202, 2005,

5 SRef-ID: 1680-7324/acp/2005-5-1053.

Kavouras, I. G., Mihalopoulos, N., and Stephanou, E. G.: Formation of Atmospheric Particles from Organic acids Produced by Forests, Nature, 395, 683-686, 1998.

Liggio, J., Li, S.-M., and McLaren, R.: Heterogeneous reactions of glyoxal on particulate matter: Identification of acetals and sulfate esters, Environ. Sci. Technol., 39, 1532-1541, 2005.

10 Limbeck, A., Kulmala, M., and Puxbaum, H.: Secondary organic aerosol formation in the atmosphere via heterogeneous reaction of gaseous isoprene on acidic particles, Geophys. Res. Lett., 30, doi:10.1029/2003GL017738, 2003.

Matsunaga, S. and Kawamura, K.: Determination of $\alpha$ - and $\beta$-Hydroxycarbonyls and dicarbonyls in snow and rain samples by GC/FID and GC/MS employing benzyl hydroxyl oxime derivatization, Anal. Chem., 72, 4742-4746, 2000.

Matsunaga, S., Mochida, M., and Kawamura, K.: Growth of organic aerosols by semi-volatile carbonyls in the forestal atmosphere, Atmos. Environ., 35, 2045-2050, 2003.

Matsunaga, S., Mochida, M., and Kawamura, K.: Variation on the atmospheric concentrations of biogenic carbonyl compounds and their removal processes in the northern forest at Moshiri, Hokkaido Island, Japan, J. Geophys. Res., 109, 4302, doi:10.1029/2003JD004100, 2004.

Matsunaga, S., Kato, S., Yoshino, A., Greenberg, J. P., Kajii, Y., and Guenther, A. B.: Gasaerosol partitioning of semi volatile carbonyls in polluted atmosphere in Hachioji, Tokyo, Geophys. Res. Lett., 32, L11805, doi:10.1029/2004GL021893, 2005.

Trainer, M., Williams, E. J., Parrish, D. D., et al.: Models and observations of the impact of natural hydrocarbons on rural ozone, Nature, 329, 705-707, 1987.

Tuazon, E. C. and Atkinson, R.: A Product Study of the Gas-Phase Reaction of Methyl Vinyl Ketone with the $\mathrm{OH}$ Radical in the Presence of $\mathrm{NO}_{x}$, Int. J. Chem. Kinet., 21, 1141-1152, 1989.

30 Tuazon, E. C. and Atkinson, R.: A Product Study of the Gas-Phase Reaction of methacrolein with the $\mathrm{OH}$ Radical in the Presence of $\mathrm{NO}_{x}$, Int. J. Chem. Kinet., 22, 591-602,1990.

ACPD

5, 11143-11156, 2005

\section{Isoprene oxidation products in the aerosols}

\section{S. N. Matsunaga et al.}

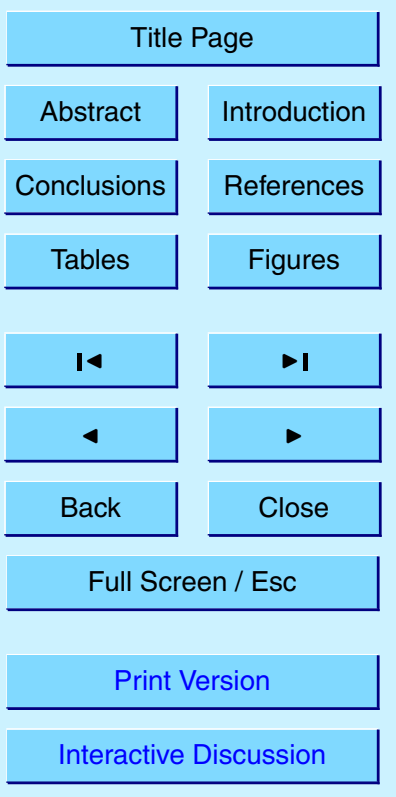

EGU 


\section{ACPD}

5, 11143-11156, 2005

\section{Isoprene oxidation products in the aerosols}

S. N. Matsunaga et al.

Table 1. Annual aerosol mass contributions (AMCs) of isoprene oxidation products on a global scale. The ranges assigned to each value represent the total uncertainties.

\begin{tabular}{lllll}
\hline & $A M C_{\mathrm{GA}}$ & $A M C_{\mathrm{HA}}$ & $A M C_{\mathrm{MG}}$ & WSOCs Total \\
\hline $\mathrm{Tg} \mathrm{yr}^{-1}$ & $14(3.9-47)$ & $12(3.5-40.6)$ & $9.7(2.9-32)$ & $\mathbf{3 5 ( 1 0 - 1 2 0 )}$ \\
$\mathrm{TgC} \mathrm{yr}^{-1}$ & $5.4(1.5-19)$ & $5.8(1.7-20)$ & $4.9(1.5-16)$ & $\mathbf{1 6 ( 4 . 7 - 5 5 )}$ \\
\hline
\end{tabular}

$A M C$ means aerosol mass contribution.

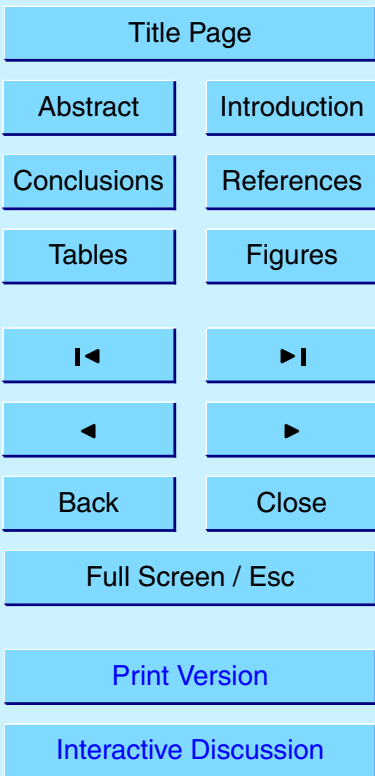

EGU 


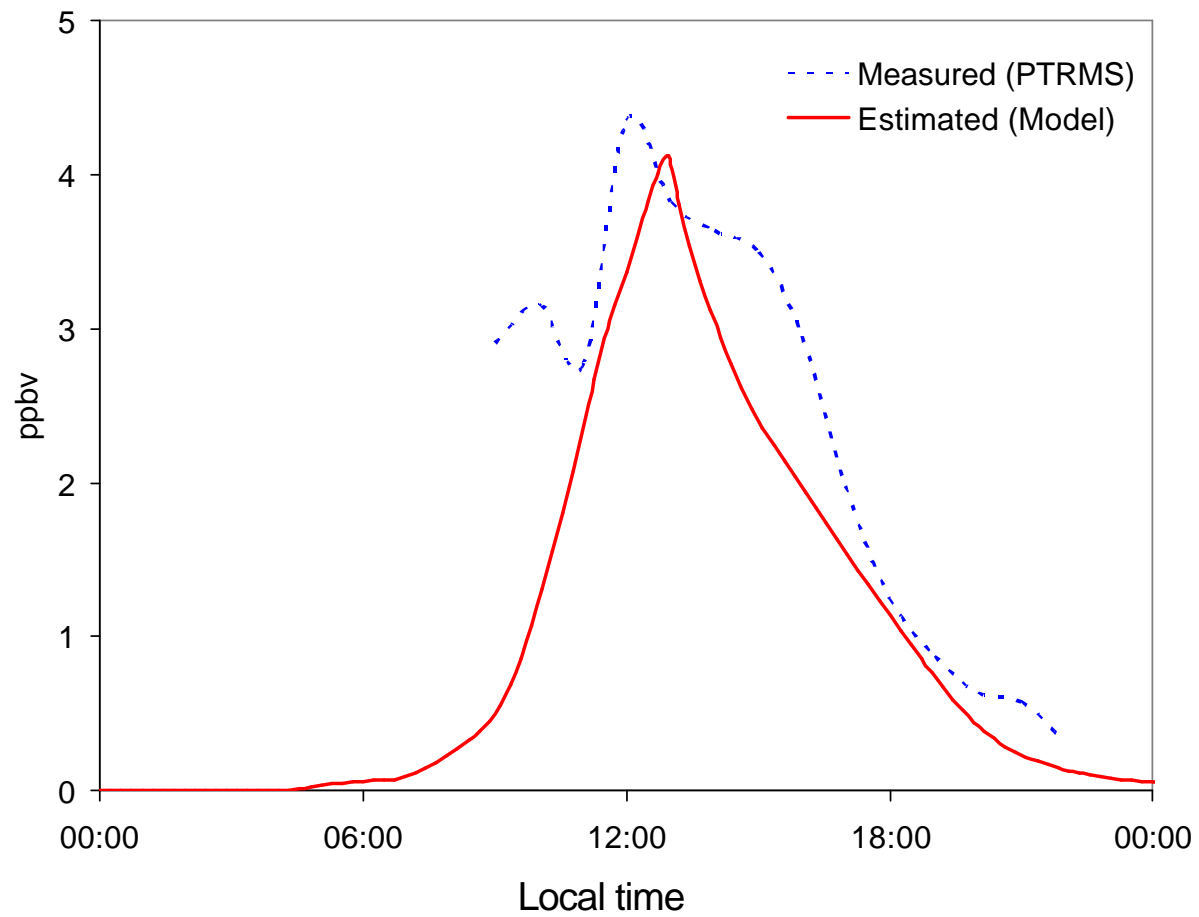

Fig. 1. Comparison of the measured concentrations (dashed line) of methacrolein (MACR) and methyl vinyl ketone (MVK) and simulated concentrations from the box model (solid line). MACR and MVK are the first generation oxidation products from isoprene and are precursors of glycolaldehyde, hydroxyacetone and methylglyoxal on 10 July. The measurement for MACR and MVK has been made with a proton transfer reaction mass spectrometer (PTR-MS). Because these two compounds are isomers, the concentrations of MACR and MVK were obtained as total concentrations.

\section{ACPD}

5, 11143-11156, 2005

\section{Isoprene oxidation products in the aerosols}

S. N. Matsunaga et al.

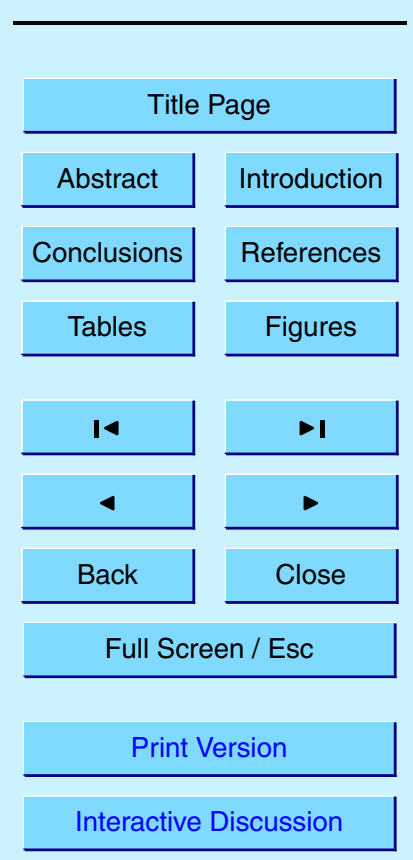



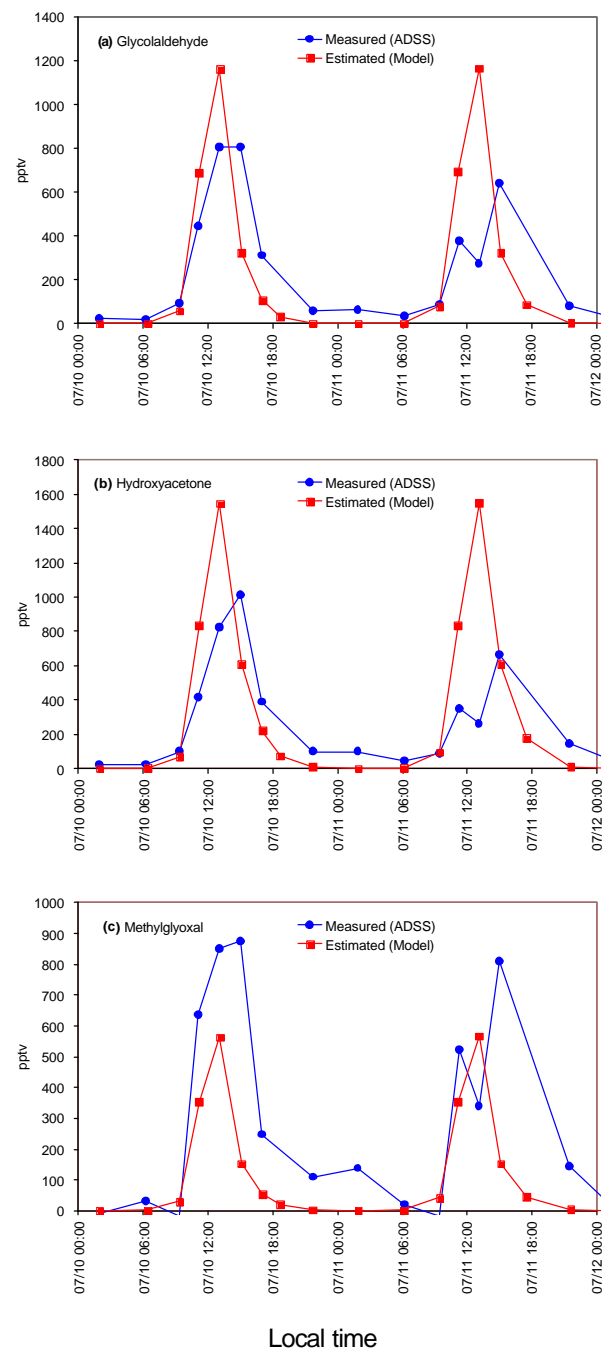

ACPD

5, 11143-11156, 2005

\section{Isoprene oxidation products in the aerosols}

S. N. Matsunaga et al.

Fig. 2. Comparison of the measured concentrations (blue circles and lines) of (a) glycolaldehyde (GA), (b) hydroxyacetone (HA) and (c) methylglyoxal (MG) between the measurements and the simulated concentrations from the box model (red squares and lines). The measurements were made with an annular denuder sampling system (ADSS) which can measure gaseous and particulate compounds. The measured concentrations in these plots represent the sum of those compounds in the gaseous and particulate phases.

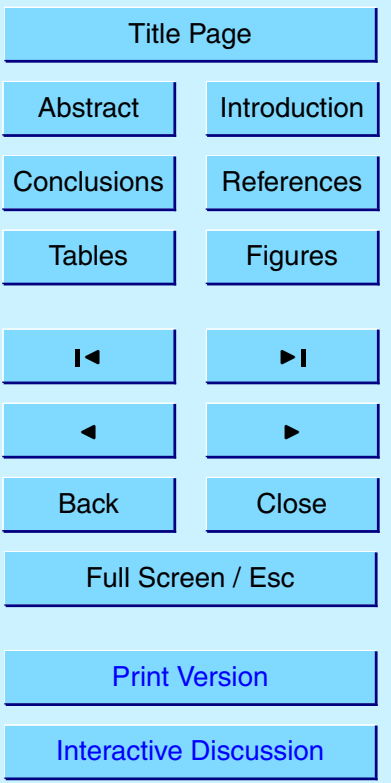

EGU 

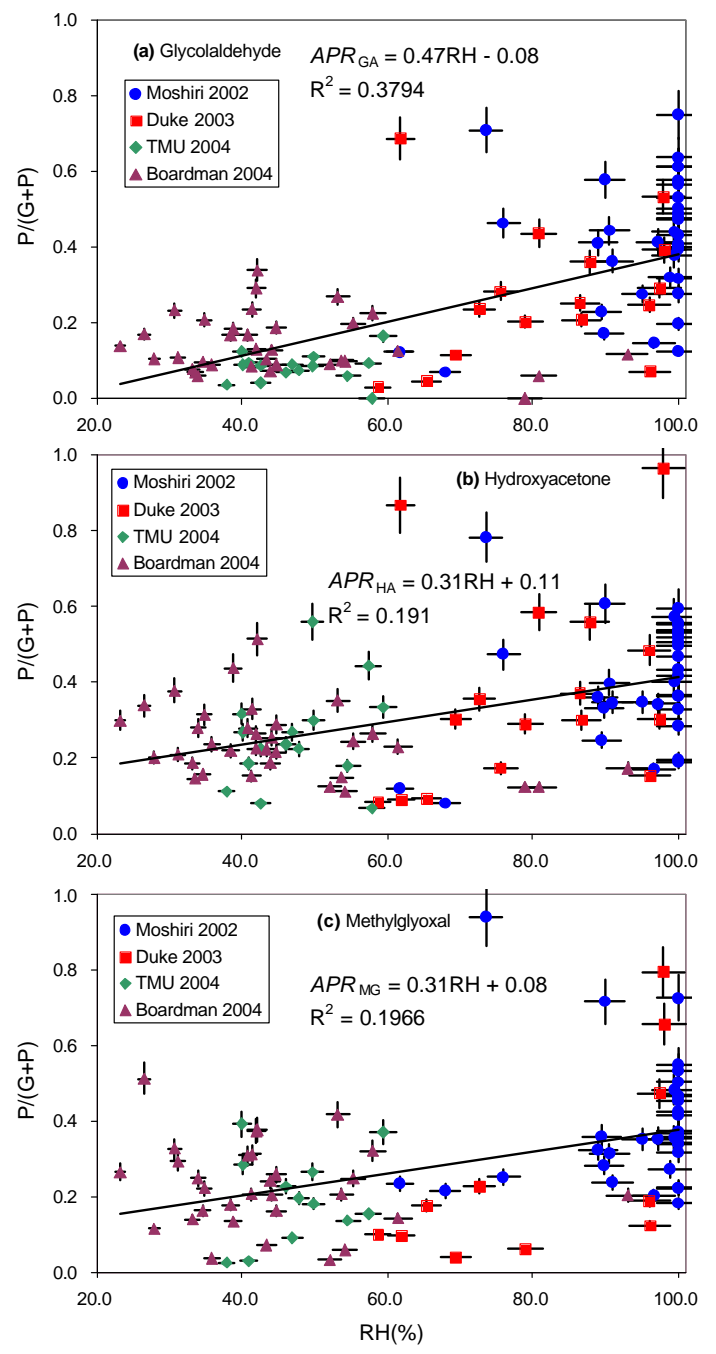

ACPD

5, 11143-11156, 2005

\section{Isoprene oxidation products in the aerosols}

S. N. Matsunaga et al.

Fig. 3. Relationship between the aerosol partition ratio $(P /(G+P))$ and relative humidity for (a) GA, (b) HA, and (c) MG obtained from four different field experiments: Moshiri, (a remote cold mountain forest in Japan), Duke (a temperate forest in a relatively polluted area in the U.S.), TMU (campus at the Tokyo Metropolitan University in Tokyo, Japan (polluted)), and Boardman (a remote poplar plantation surrounded by a desert in the U.S.). Vertical and horizontal bars indicate uncertainties of the values based on analytical error of the WSOCs and error of hygrometer, respectively.

\section{Title Page}

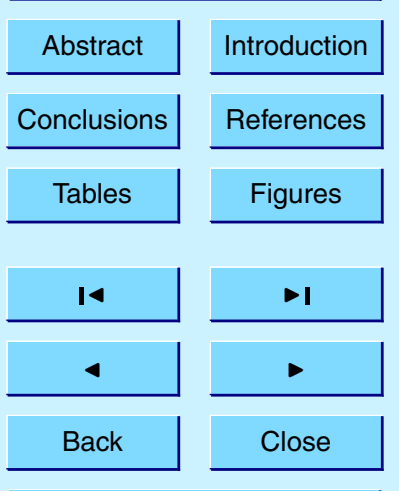

Full Screen / Esc

Print Version

Interactive Discussion 